\title{
PENGARUH KONSUMSI TEMPE KEDELAI GROBOGAN TERHADAP PROFIL SERUM, HEMATOLOGI DAN ANTIOKSIDAN TIKUS
}

\author{
[Effect of Grobogan Soybean Tempe Consumption on Rats'Serum Profiles, \\ Hematology, and Antioxidant]
}

\author{
Made Astawan $^{1) \star}$, Tutik Wresdiyati $^{2}$, dan Jefriaman Sirait ${ }^{1)}$ \\ ${ }^{1)}$ Departemen IImu dan Teknologi Pangan, Fakultas Teknologi Pertanian, Institut Pertanian Bogor, Bogor \\ 2) Departemen Anatomi, Fisiologi dan Farmasi, Fakultas Kedokteran Hewan, Institut Pertanian Bogor, Bogor
}

Diterima 12 Mei 2015 / Disetujui 25 September 2015

\begin{abstract}
ABTRACT
Tempe is a potential source of protein for 250 million people in Indonesia. Indonesian soybean demand reached 2.2 million tons per year, and 1.3 million tons of which are used for tempe production. Approximately $70 \%$ of the soybeans are imported from different countries. To improve national food security, it is important to use local soybean as a raw material. Therefore, this study used Grobogan local soybean as raw material. The pupose of this study was to evaluate the impact of the consumption of tempe (from local soybean Grobogan) in the long tem, ie over a 90-day subchronic test using rats as a model. Parameters measured were serum biochemical profile, hematology, malonaldehyde (MDA), and superoxide dismutase (SOD) in liver and kidney organs of rats. This research was conducted using three groups of rats which were fed tempe, boiled soybean, and casein as a source of protein in the ration. Data feed convertion efficiency showed that tempe of Grobogan soybean had a better protein quality than that of boiled soybean and casein. As compared to the groups of rats fed with boiled soybean and casein, the group fed with tempe had a higher HDL cholesterol, however no significant difference was observed in the hematological parameters, MDA and SOD in liver and kidney organs. This suggests consumption of tempe made from Grobogan soybean in the long term does not have a negative impacton health.
\end{abstract}

Keywords: hematology, tempe Grobogan soybean, $M D A$, serum profile, $S O D$

\section{ABSTRAK}

Tempe menupakan sumber protein yang sangat potensial bagi 250 juta penduduk Indonesia. Kebutuhan kedelai Indonesia mencapai 2.2 juta ton/tahun, dan 1.3 juta ton di antaranya digunakan untuk produksi tempe. Sekitar $70 \%$ dari kedelai tersebut diimpor dari berbagai negara. Untuk meningkatkan ketahanan pangan nasional, sangat penting untuk menggunakan kedelai lokal sebagai bahan baku pembuatan tempe. Oleh karena itu penelitian ini menggunakan kedelai lokal Grobogan sebagai bahan bakunya. Tujuan dari penelitian ini adalah untuk mengevaluasi dampak konsumsi tempe (dari kedelai lokal Grobogan) dalam jangka panjang, yaitu melalui uji subkronis selama 90 hari dengan menggunakan tikus percobaan. Parameter yang diamati adalah profil biokimia senum, hematologi, malonaldehida (MDA), dan superoksida dismutase (SOD) pada organ hati dan ginjal tikus percobaan. Penelitian ini dilakukan dengan menggunakan tiga kelompok tikus yang diberi pakan tempe, kedelai rebus dan kasein sebagai sumber protein di dalam ransum. Data feed convertion efficiency menunjukkan tempe kedelai Grobogan memiliki kualitas protein yang lebih baik dibandingkan kedelai rebus dan kasein. Dibandingkan dengan tikus kelom pok kedelai rebus dan kasein, maka tikus kelompok tempe memiliki kolesterol HDL yang lebih tingg i, tetapi tidak berbeda nyata pada parameter hematologi, MD A dan SOD hati dan ginjal tikus percobaan. Hal ini menunjukkan konsumsi tempe dari kedelai Grobogan dalam jangka panjang tidak berdampak negatif terhadap kesehatan.

Kata kunci: hematologi, tempe kedelai Grobogan, MDA, profil serum, SOD

\section{PENDAHULUAN}

Dewasa ini kebutuhan kedelai nasional sangat besar, rata-rata mencapai 2.2 juta ton per tahun (Astawan et al., 2015). Sekitar 70\% dari kedelai tersebut diimpor dari berbagai negara. Untuk meningkatkan ketahanan pangan nasional, sangat penting untuk menggunakan kedelai lokal sebagi bahan baku pembuatan tempe.

${ }^{*}$ Penulis Korespondensi:

E-mail: mastawan@yahoo.com 
Sekitar 1.3 juta ton kedelai per tahun digunakan untuk pembuatan tempe, yang merupakan sumber protein murah bagi masyarakat Indonesia (Astawan et al., 2014). Tempe merupakan pangan olahan hasil fermentasi kedelai oleh kapang Rhizopus sp. Proses fermentasi akan mengubah kedelai menjadi tempe yang memiliki aroma, citarasa, tekstur, penampilan, nilai gizi, dan daya cerna yang lebih baik (Nout dan Kiers, 2005). Selain mengandung protein yang tinggi, tempe juga mengandung isoflavon yang dapat menangkal radikal bebas (Watanabe et al., 2007; Astuti, 2008; Utari et al., 2010; Astawan, 2013). Beberapa khasiat tempe bagi kesehatan adalah menurunkan risiko: penyakit jantung dan stroke, osteoporosis, kanker, gangguan pencernaan, overweigt dan obesitas, serta diare (Babu et al., 2009). Konsumsi tempe juga dapat menurunkan senyawa malonaldehida dan glukosa darah (Desminarti et al., 2012). Seiring dengan perkembangan produk olahan tempe, pertumbuhan konsumsi tempe nasional juga meningkat. Rata-rata konsumsi tempe nasional mencapai $8,5 \mathrm{~kg} / \mathrm{kapita} /$ tahun (Astawan, 2015). Di masa mendatang konsumsi tempe dan produk turunannya akan semakin meningkat, terutama akibat meningkatnya jumlah vegetarian di dunia.

Dalam rangka untuk meningkatkan ketahanan, kedaulatan dan kemandirian pangan nasional sesuai amanah Undang-undang Pangan No. 18 tahun 2012, maka sangat penting untuk menggunakan kedelai lokal sebagai bahan baku pembuatan tempe. Penelitian ini bertujuan untuk memberikan bukti ilmiah dampak konsumsi tempe kedelai Grobogan dalam jangka panjang terhadap profil biokimia serum, hematologi, kadar malonaldehida, serta superoksida dismutase pada organ hati dan ginjal tikus percobaan. Sebagai pembanding digunakan kedelai rebus dan kasein. Cara penyiapan kedelai rebus persis sama dengan pada pembuatan tempe, hanya bedanya tidak mengalami proses fermentasi. Dalam hal ini kedelai rebus digunakan sebagai pembanding untuk melihat pengaruh proses fermentasi pada pembuatan tempe terhadap profil serum, hematologi dan antioksidan.

\section{BAHAN DAN METODE}

\section{Bahan}

Bahan baku yang digunakan adalah kacang kedelai (Glycine max) varietas Grobogan yang diperoleh dari petani di Grobogan, Jawa Tengah. Tikus percobaan yang digunakan adalah tikus putih jantan galur Sprague Dawley umur 28 hari yang diperoleh dari BPOM RI, Jakarta. Bahan-bahan yang digunakan untuk pembuatan ransum tikus adalah tepung tempe, tepung kedelai rebus, kasein, pati jagung, carboximethylcelulose (CMC) (Sigma-
Aldrich, USA), minyak jagung, campuran mineral dan campuran vitamin.

\section{Pembuatan tempe}

Proses pembuatan tempe dimulai dengan pembersihan kedelai, perendaman dengan air selama 1 jam, perebusan selama 30 menit, perendaman dalam air perebus selama 12 jam (hingga $\mathrm{pH}$ sekitar 4,0-4,5), pemisahan kulit ari, pencucian hingga bersih, penirisan, penambahan ragi, pengemasan, dan fermentasi selama 40 jam.

\section{Pembuatan tepung tempe}

Pembuatan tepung tempe dilakukan dengan cara pengirisan tempe menggunakan slicer, pemblansiran dengan uap panas (tekanan 1 bar selama 2 menit), pengeringan oven dengan suhu $60^{\circ} \mathrm{C}$ selama 8 jam, penggilingan dengan disc mill (Crompton Greves, India), dan pengayakan dengan saringan 60 mesh.

\section{Pembuatan tepung kedelai rebus}

Pembuatan tepung kedelai rebus dimulai dari pembersihan atau penyortiran kedelai, perendaman selama 6 jam, perebusan selama 30 menit, pengupasan kulit ari kedelai, penirisan, pengeringan dengan oven pada suhu $60^{\circ} \mathrm{C}$, penepungan dengan disc mill, dan penyaringan dengan ayakan 60 mesh.

\section{Pembuatan ransum}

Pembuatan ransum tikus percobaan dibedakan berdasarkan sumber protein, yaitu tepung tempe, tepung kedelai rebus, dan kasein sebagai kontrol. Jumlah ransum yang diberikan disesuaikan dengan kebutuhan harian tikus dan komposisinya disesuaikan dengan standar AOAC (2005), yang terdiri dari: protein $10 \%$, lemak $8 \%$, air $5 \%$, serat $1 \%$, vitamin $1 \%$, mineral $5 \%$, dan karbohidrat $70 \%$ (Muchtadi et al., 1992).

\section{Analisis proksimat sampel}

Analisis proksimat dilakukan pada tepung tempe, tepung kedelai rebus, dan kasein. Hasil analisis akan menjadi acuan dalam formulasi ransum tikus percobaan. Analisis proksimat terdiri dari analisis kadar air (metode oven, AOAC, 2005), analisis kadar abu (metode pengabuan kering, AOAC, 2005), analisis kadar lemak (metode Soxhlet, AOAC, 2005), analisis kadar protein kasar (metode Kjedhal, AOAC, 2005), dan analisis serat kasar (metode asam basa kuat, AOAC, 2005). Kadar karbohidrat ditentukan secara by difference.

\section{Masa adaptasi tikus percobaan}

Penelitian ini menggunakan tikus percobaan sebagai model yang telah mendapatkan Ethical Approval dari Ketua Komisi Etik Hewan IPB (ACUC No: 06-2013 IPB). Tikus yang digunakan dalam penelitian diadaptasikan terlebih dahulu selama tiga 
hari dengan pemberian ransum standar (kasein sebagai sumber protein) dan air minum secara ad libitum. Tikus ditempatkan dalam kandang secara individual dengan kondisi cahaya dan ventilasi yang cukup pada suhu ruang (sekitar $20-25^{\circ} \mathrm{C}$ ). Masa adaptasi bertujuan untuk membiasakan tikus terhadap lingkungan percobaan.

\section{Seleksi tikus dan kelompok perlakuan}

Setelah masa adaptasi, tikus diseleksi berdasarkan keseragaman bobot tubuh dan dikelompokkan menjadi tiga, yaitu kelompok tikus yang diberi ransum standar (kasein), ransum tepung tempe, dan ransum tepung kedelai rebus. Setiap tikus dalam satu kelompok memiliki perbedaan bobot kurang dari 10 gram dan antar kelompok memiliki perbedaan maksimal 5 gram.

\section{Masa percobaan}

Selama 90 hari masa percobaan, tikus diberikan ransum sesuai dengan kelompok perlakuannya dan air minum secara ad libitum. Tikus dikandangkan secara individual dengan kondisi cahaya dan ventilasi yang cukup pada suhu ruang (sekitar $20-25^{\circ} \mathrm{C}$ ). Selama masa percobaan, dilakukan pengamatan konsumsi ransum setiap hari dan berat badan tikus setiap enam hari sekali.

\section{Persiapan serum dan organ}

Pada akhir masa percobaan, dilakukan pembedahan terhadap semua tikus. Tikus dibius menggunakan campuran larutan ketamine (llium, Australia) dan xylazine (Interchemie, Netherland). Darah diambil dari jantung dengan menggunakan syringe (BD, Belgium), dimasukkan ke dalam tabung sentrifus, disentrifus pada $3000 \mathrm{rpm}$ selama 10 menit, dan dipisahkan serumnya. Serum yang diperoleh dimasukkan ke dalam test tube (Eppendorf, Germany) untuk dianalisis. Organ tikus (ginjal dan hati) diambil dengan gunting bedah dan pinset, ditimbang dengan neraca analitik, dimasukkan ke dalam wadah plastik dan dibekukan untuk keperluan analisis selanjutnya.

\section{Analisis hematologi dan serum}

Analisis hematologi dilakukan sesuai Aboderin dan Oyetayo (2006), yaitu dengan menggunakan $0,5 \mathrm{~mL}$ darah yang dimasukkan ke dalam tabung yang diberi anti-koagulan ethylene diamine tetraacetic acid (EDTA) (BDH, USA). Analisis hematologi meliputi kadar hemoglobin, eritrosit, leukosit, trombosit, dan hematokrit, yang dilakukan dengan alat hematology analyzer (Medonic M-series Haematology Analyzer, Boule Medical Stockholm Sweden). Profil serum meliputi kadar glukosa, kolesterol, trigliserida, high density lipoprotein (HDL), low density lipoprotein (LDL), ureum, asam urat, serum glutamic oxaloa-cetic transaminase
(SGOT), serum glutamic pyruvic transaminase (SGPT), protein total, dan albumin.

\section{Analisis kadar malonaldehida hati dan ginjal (AOAC, 2005)}

Sebanyak 1 gram hati atau ginjal dihancurkan dalam kondisi dingin dengan $5 \mathrm{~mL}$ larutan Phosphat Buffer Saline (PBS) (Sigma-Aldrich, USA) yang mengandung 11,5 gram $\mathrm{KCl} / \mathrm{L}$. Homogenat yang diperoleh kemudian disentrifus pada 4000 rpm selama 10 menit sampai diperoleh supernatan jernih. Selanjutnya $1 \mathrm{~mL}$ supernatan hati, ginjal atau larutan kerja (standar) 1,1-3,3-tetraethoxypropane (TEP) (Sigma-Aldrich, USA) dicampur dengan 4,0 $\mathrm{mL}$ larutan $\mathrm{HCl} 0,25 \mathrm{~N}$ dingin yang mengandung $15 \%$ trichloroacetic acid (TCA) (Merck, Germany), $0,38 \%$ thiobarbituric acid (TBA) (Merck, Germany), dan 0,5\% butylatedhydroxytoluene (BHT) (Merck, Germany), kemudian divortex. Campuran yang diperoleh dipanaskan pada suhu $80^{\circ} \mathrm{C}$ dengan menggunakan penangas selama 1 jam. Setelah dingin, campuran disentrifus $3,500 \mathrm{rpm}$ selama 10 menit. Supernatan jernih diukur absorbansinya pada $532 \mathrm{~nm}$ dan diplotkan pada kurva standar TEP untuk menghitung kadar malonaldehida (MDA) sampel.

\section{Analisis aktivitas superoksida dismutase hati dan ginjal (Misra dan Fridovich, 1972)}

Sampel hati atau ginjal dihancurkan dan diekstraksi dengan buffer fosfat $\mathrm{pH} 7$, dengan perbandingan 1:10. Hasil ekstraksi disentrifus dengan kecepatan 3000 rpm dengan jari-jari sentrifus sebesar $17,90 \mathrm{~cm}$ selama 10 menit dalam keadaan dingin. Pengukuran serapan dilakukan dengan cara memasukkan $2800 \mu \mathrm{L}$ buffer natrium karbonat $\mathrm{pH}$ 10,$2 ; 100 \mu \mathrm{L}$ sampel supernatan yang mengandung superoksida dismutase (SOD) dan $100 \mu \mathrm{L}$ larutan epinefrin ke dalam tabung reaksi. Kemudian serapan dibaca pada panjang gelombang $480 \mathrm{~nm}$ pada menit ke 1, 2, 3, dan 4 .

\section{Analisis data}

Data ditampilkan sebagai nilai rata-rata \pm standar deviasi. Data dianalisis menggunakan uji ragam analysis of variance (ANOVA) pada taraf signifikansi 0,05. Uji beda lanjut dilakukan dengan uji Duncan. Pengolahan data menggunakan program SPSS versi 16.0 (Chicago, USA).

\section{HASIL DAN PEMBAHASAN}

\section{Proksimat sampel}

Analisis proksimat dilakukan untuk mengetahui komposisi kimia sampel (Tabel 1). Analisis proksimat menunjukkan kandungan protein, abu, serat kasar dan air pada kedelai hampir sama dengan tempe. Perbedaan antara tempe dan kedelai 
terdapat pada kualitas zat gizinya. Tempe memiliki kualitas zat gizi yang lebih baik disbandingkan kedelai, akibat proses fermentasi yang mengubah komponen karbohidrat, protein dan lemak menjadi lebih sederhana (Nout dan Kiers, 2005). Babu et al. (2009) melaporkan bahwa fermentasi kedelai menjadi tempe dapat meningkatkan daya cerna karbohidrat karena adanya enzim a-galaktosidase yang mendegradasi rafinosa, stakiosa dan beberapa oligosakarida.

Tabel 1. Komposisi kimia tepung tempe dibandingkan kasein dan tepung kedelai rebus

\begin{tabular}{lccc}
\hline $\begin{array}{c}\text { Parameter } \\
(\%)\end{array}$ & Kasein & $\begin{array}{c}\text { Tepung } \\
\text { Tempe }\end{array}$ & $\begin{array}{c}\text { Tepung Kedelai } \\
\text { Rebus }\end{array}$ \\
\hline Kadar & $89,4 \pm$ & $51,7 \pm$ & $51,1 \pm$ \\
protein & 2,1 & 2,0 & 3,5 \\
Kadar & $0,3 \pm$ & $25,4 \pm$ & $25,3 \pm$ \\
lemak & 0,0 & 1,6 & 1,7 \\
Kadarabu & $0,6 \pm$ & $1,8 \pm$ & $2,6 \pm$ \\
& 0,1 & 0,1 & 0,2 \\
Kadar serat & $0,5 \pm$ & $6,5 \pm$ & $7,6 \pm$ \\
kasar & 0,0 & 0,5 & 0,5 \\
Air & $9,0 \pm$ & $4,3 \pm$ & $5,5 \pm$ \\
& 0,1 & 0,4 & 0,5 \\
Karbohidrat & $0,7 \pm$ & $16,8 \pm$ & $15,6 \pm$ \\
& 0,0 & 1,2 & 1,0 \\
\hline
\end{tabular}

Berdasarkan hasil analisis proksimat sampel, kemudian ditentukan formulasi ransum yang akan diberikan kepada tikus percobaan (Tabel 2). Pada ransum kelompok tikus yang diberi tempe dan kedelai rebus tidak ditambahkan CMC karena tepung tempe dan tepung kedelai rebus sudah mengandung serat kasar yang cukup untuk kebutuhan harian tikus percobaan.

Tabel 2. Komposisi ransum tikus percobaan berdasarkan sumber protein per $1000 \mathrm{~g}$

\begin{tabular}{lccc}
\hline \multirow{2}{*}{$\begin{array}{l}\text { Komponen } \\
\text { Penyusun (g) }\end{array}$} & \multicolumn{1}{c}{ Kelompok Perlakuan (Sumber Protein) } \\
\cline { 2 - 4 } & Kasein & $\begin{array}{c}\text { Tepung } \\
\text { Tempe }\end{array}$ & $\begin{array}{c}\text { Tepung } \\
\text { Kedelai Rebus }\end{array}$ \\
\hline $\begin{array}{l}\text { Sampel } \\
\text { protein }\end{array}$ & 112 & 193 & 196 \\
Minyak & 80 & 31 & 30 \\
jagung & & & \\
Mineral mix & 49 & 46 & 45 \\
Vitamin mix & 10 & 10 & 10 \\
CMC & 9 & - & - \\
Air & 39 & 42 & 39 \\
Pati jagung & 701 & 678 & 680 \\
\hline
\end{tabular}

\section{Kenaikan berat badan tikus dan konsumsi ransum}

Jumlah konsumsi ransum dan kenaikan berat badan tikus pada ketiga kelompok perlakuan selama 90 hari percobaan disajikan pada Tabel 3. Jumlah konsumsi ransum tikus kelompok kasein nyata lebih tinggi $(P<0,05)$ dibandingkan tikus kelompok tempe dan kelompok kedelai rebus. Hal ini dikarenakan kedelai dan tempe memiliki indeks glikemik yang rendah (Astawan, 2009; Astawan, 2013) sehingga dapat mempertahankan glukosa darah stabil, sehingga tikus tidak mudah lapar. Tempe juga mengandung serat pangan yang menyebabkan tikus lebih cepat kenyang (Mursyid et al., 2014). Semakin besar jumlah konsumsi ransum seharusnya memberikan kenaikan berat badan yang semakin tinggi, namun hasil yang diperoleh pada Tabel 3 ternyata berbeda. Kelompok tikus yang diberi ransum kasein, walaupun memiliki jumlah konsumsi ransum terbesar, tetapi tidak mengalami kenaikan berat badan tertinggi. Kenaikan berat badan tikus kelompok tempe ny ata lebih tinggi $(P<0,05)$ dibandingkan tikus kelompok kedelai rebus, tetapi tidak berbeda dengan tikus kelompok kasein. Hal ini menunjukkan bahwa kualitas protein tempe lebih baik disbandingkan protein kedelai rebus, tetapi setara dengan protein kasein. Hal ini didukung oleh hasil penelitian Mursyid et al. (2014) yang melaporkan kualitas protein tempe setara dengan protein kasein.

Tabel 3. Konsumsi ransum, kenaikan berat badan dan food convertion efficiency tikus setelah 90 hari percobaan

\begin{tabular}{lccc}
\hline \multirow{2}{*}{$\begin{array}{c}\text { Parameter } \\
\text { Selama }\end{array}$} & \multicolumn{3}{c}{ Perlakuan (Sumber Protein) } \\
\cline { 2 - 4 } Percobaan & Kasein & $\begin{array}{c}\text { Tepung } \\
\text { Tempe }\end{array}$ & $\begin{array}{c}\text { Tepung } \\
\text { Kedelai Rebus }\end{array}$ \\
\hline Total konsumsi & $1983 \pm$ & $1813 \pm$ & $1797 \pm$ \\
ransum (g) & $109^{\mathrm{b}}$ & $81^{\mathrm{a}}$ & $51^{\mathrm{a}}$ \\
Kenaikan berat & $239 \pm$ & $271 \pm$ & $231^{ \pm} \pm$ \\
badan (g) & $26^{\mathrm{ab}}$ & $26^{\mathrm{b}}$ & $20^{\mathrm{a}}$ \\
Food convertion & $12^{ \pm}$ & $15 \pm$ & $12^{ \pm}$ \\
efficiency $(\%)$ & $1^{\mathrm{a}}$ & $2^{\mathrm{b}}$ & $1^{\mathrm{a}}$ \\
\hline
\end{tabular}

Keterangan: Nilai yang diikuti oleh huruf yang berbeda pada baris yang sama menunjukkan berbeda nyata $(P<0,05)$

Semakin tinggi nilai food convertion efficiency (FCE) maka semakin tinggi tingkat efisiensi penggunaan ransum, demikian sebaliknya. Data yang disajikan pada Tabel 3 menunjukkan FCE tikus kelompok tempe nyata lebih tinggi $(P<0,05)$ dibandingkan tikus kelompok kasein dan kelompok kedelai rebus.

\section{Rasio berat organ dengan berat badan}

Data pada Tabel 4 menunjukkan berat relatif (\% terhadap bobot tubuh) organ hati, testis dan ginjal tikus tidak berbeda nyata $(P>0,05)$ antar perlakuan. Hal ini disebabkan oleh as upan protein pada ketiga kelompok tikus yang tidak berbeda nyata satu sama lain. Hal ini juga menunjukkan konsumsi tempe dan kedelai rebus dalam jangka panjang tidak menimbulkan dampak samping (pembengkakan) pada organ tikus. Hal ini sejalan dengan hasil penelitian Suwarno et al. (2013) yang menyatakan pemberian ransum tempe dari kedelai transgenik dan nontransgenik tidak berpengaruh terhadap berat relatif organ tikus percobaan. 
Tabel 4. Berat relatif organ terhadap bobot tubuh tikus setelah 90 hari percobaan

\begin{tabular}{lccc}
\hline $\begin{array}{l}\text { Kelompok } \\
\text { Perlakuan }\end{array}$ & $\begin{array}{c}\text { Berat } \\
\text { Relatif Hati } \\
(\%)\end{array}$ & $\begin{array}{c}\text { Berat } \\
\text { Relatif } \\
\text { Testis (\%) }\end{array}$ & $\begin{array}{c}\text { Berat } \\
\text { Relatif } \\
\text { Ginjal (\%) }\end{array}$ \\
\hline $\begin{array}{l}\text { Kasein } \\
\text { Tepung }\end{array}$ & $3,0 \pm 0,2^{\mathrm{a}}$ & $0,9 \pm 0,1^{\mathrm{a}}$ & $0,5 \pm 0^{\mathrm{a}}$ \\
tempe & $3,0 \pm 0,1^{\mathrm{a}}$ & $0,9 \pm 0,1^{\mathrm{a}}$ & $0,5 \pm 0^{\mathrm{a}}$ \\
$\begin{array}{l}\text { Tepung } \\
\text { kedelai } \\
\text { rebus }\end{array}$ & $3,0 \pm 0,2^{\mathrm{a}}$ & $0,9 \pm 0,1^{\mathrm{a}}$ & $0,5 \pm 0,1^{\mathrm{a}}$ \\
\hline $\begin{array}{l}\text { Keterangan: Nilai yang diikuti oleh huruf yang sama pada } \\
\text { kolom yang sama menunjukkan tidak berbeda nyata } \\
(P>0,05)\end{array}$
\end{tabular}

\section{Biokimia serum}

Analisis biokimia serum merupakan para-mater yang sensitif untuk mengamati kesehatan tikus dan untuk mengetahui ada atau tidaknya kelainan pada darah dari ketiga perlakuan. Analisis biokimia serum darah dapat dilihat pada Tabel 5. Kandungan karbohidrat pada ransum yang tidak berbeda jauh menjadikan kadar glukosa darah ketiga kelompok tikus tidak berbeda nyata $(P>0,05)$. Faktor pada tempe yang dapat menurunkan kadar glukosa darah adalah protein, isoflavon, serat pangan dan indeks glikemik yang rendah (Villegas et al., 2008).

Kadar kolesterol, LDL dan trigliserida serum ketiga kelompok tikus tidak berbeda nyata satu sama lainnya (Tabel 5). Tabel 5 juga menunjukkan nilai kolesterol HDL tikus kelompok tepung tempe nyata lebih besar $(P<0,05)$ dibandingkan nilai $\mathrm{HDL}$ kelompok tikus lainnya. Sebaliknya, nilai kolesterol LDL tikus kelompok tepung tempe tidak berbeda dengan kelompok kasein dan tepung kedelai rebus. Keberadaan asam oleat, linoleat dan linolenat pada tempe berpotensi untuk meningkatkan kolestrol HDL dan menurunkan kolesterol LDL. Tingginya kadar HDL mengurangi terjadinya pengendapan dan pembentukkan plak dalam sistem peredaran darah (Astawan et al., 2005). Berdasarkan hasil analisis HDL yang diperoleh, tempe dapat dijadikan pangan alternatif untuk meningkatkan HDL darah sehingga dapat digunakan untuk mencegah penyakit kardiovaskuler. Hasil meta-analisis terbaru terhadap 20 parallel-design studies dan 23 crossover studies, melaporkan bahwa konsumsi rutin 1-2 porsi (15-30 g) protein kedelai setiap hari berpengaruh secara nyata terhadap perbaikan profil lipoprotein serum dalam penurunan risiko penyakit jantung coroner (Anderson dan Bush, 2011).

Nilai kreatinin, asam urat dan SGOT tikus pada ketiga kelompok tidak berbeda nyata $(P>0,05)$. Hal ini membuktikan bahwa konsumsi tempe dan kedelai rebus tidak meningkatkan nilai kreatinin, asam urat dan ureum dalam darah. Dengan demikian persepsi masyarakat bahwa konsumsi tempe secara terus-menerus dalam jangka waktu lama dapat meningkatkan asam urat, tidak terbukti pada penelitian ini. Hal ini sejalan dengan hasil penelitian Messina et al. (2011) yang menunjukkan tidak satupun dari enam studi epidemiologi yang diidentifikasi memberikan bukti bahwa konsumsi kedelai menyebabkan peningkatan sirkuasi asam urat, hiperurisemia, atau gout. Evaluasi terhadap data dari lima studi intervensi pada manusia menunjukkan protein kedelai tidak meningkatkan kadar asam urat di dalam serum, sehingga konsumsi pangan berbahan kedelai seperti yang biasa dilakukan di Asia tidak relevan secara klinis dianggap sebagai penyebab kenaikan asam urat (Messina et al., 2011). Kadar SGPT tikus kelompok ransum tempe tidak berbeda nyata dengan kelompok kasein dan kedelai rebus. Tingginya kadar SGPT dalam darah umumnya menunjukkan kerja fungsi hati yang terganggu. Pada penelitian ini, kenaikan SGPT pada kelompok kedelai rebus belum berdampak pada kerusakan hati, yang ditunjukkan oleh tidak adanya perbedaan berat relatif organ hati terhadap bobot tubuh (Tabel 4). Nilai protein total dan albumin ketiga kelompok tikus tidak berbeda nyata (Tabel 5).

Tabel 5. Profil biokimia serum tikus yang diberi pakan kasein, tepung tempe dan tepung kedelai rebus setelah 90 hari percobaan

\begin{tabular}{lccc}
\hline \multirow{2}{*}{ Parameter } & \multicolumn{2}{c}{ Kelompok Perlakuan (Sumber Protein) } \\
\cline { 2 - 4 } & Kasein & Tepung Tempe & Tepung Kedelai Rebus \\
\hline Glukosa darah (mg/dL) & $241 \pm 41,9^{\mathrm{a}}$ & $216,2 \pm 18,9^{\mathrm{a}}$ & $202,4 \pm 11,7^{\mathrm{a}}$ \\
Kolesterol (mg/dL) & $62,4 \pm 8,7^{\mathrm{a}}$ & $58,2 \pm 7,9^{\mathrm{a}}$ & $57,4 \pm 6,6^{\mathrm{a}}$ \\
Trigliserida (mg/dL) & $55,8 \pm 4,6^{\mathrm{a}}$ & $51,4 \pm 8,6^{\mathrm{a}}$ & $48,4 \pm 5,8^{\mathrm{a}}$ \\
HDL (mg/dL) & $47,4 \pm 6,5^{\mathrm{a}}$ & $63,0 \pm 5,7^{\mathrm{b}}$ & $54,8 \pm 4,3^{\mathrm{a}}$ \\
LDL $(\mathrm{mg} / \mathrm{dL})$ & $34,6 \pm 3,9^{\mathrm{a}}$ & $33,6 \pm 4,2^{\mathrm{a}}$ & $34,2 \pm 5,8^{\mathrm{a}}$ \\
Kreatinin (mg/dL) & $0,8 \pm 0,1^{\mathrm{a}}$ & $0,8 \pm 0,1^{\mathrm{a}}$ & $0,7 \pm 0,1^{\mathrm{a}}$ \\
Asam urat (mg/dL) & $0,6 \pm 0,3^{\mathrm{a}}$ & $0,4 \pm 0,2^{\mathrm{a}}$ & $0,4 \pm 0,2^{\mathrm{a}}$ \\
SGOT (U/L) & $101,8 \pm 20,9^{\mathrm{a}}$ & $84,2 \pm 12,7^{\mathrm{a}}$ & $114,0 \pm 39,2^{\mathrm{a}}$ \\
SGPT (U/L) & $40,6 \pm 6,3^{\mathrm{a}}$ & $46,0 \pm 9,2^{\mathrm{ab}}$ & $55,6 \pm 13,9^{\mathrm{b}}$ \\
Total protein (g/dL) & $6,6 \pm 0,5^{\mathrm{a}}$ & $6,2 \pm 0,2^{\mathrm{a}}$ & $6,2 \pm 0,2^{\mathrm{a}}$ \\
Albumin (g/dL) & $3,2 \pm 0,3^{\mathrm{a}}$ & $3,2 \pm 0,1^{\mathrm{a}}$ & $3,2 \pm 0,1^{\mathrm{a}}$ \\
\hline Keterangan:Niligang
\end{tabular}

Keterangan: Nilai yang diikuti oleh huruf yang berbeda pada baris yang sama menunjukkan berbeda nyata $(P<0,05)$ 
Hal ini mendukung penggunaan tempe dan kedelai rebus sebagai pangan alternatif pengganti susu. Dengan demikian konsumsi tempe dan kedelai rebus dapat membantu menormalkan kadar total protein dan albumin serum. Hasil penelitian ini sejalan dengan hasil penelitian lainnya yang melaporkan bahwa pemberian ransum kasein dan kedelai non-transgenik tidak berpengaruh pada parameter serum darah (Qi et al., 2012; Daleprane et al., 2009; Appenzeller et al., 2008; Maskar et al., 2015).

\section{Hematologi darah}

Analisis hematologi merupakan analisis darah yang digunakan untuk mengetahui kadar hemoglobin, leukosit, hematokrit, eritrosit, dan trombosit. Turner et al. (2008) menjelaskan bahwa tujuan analisis hematologi adalah mengamati kelainan hematologi seperti jumlah dan fungsi sel darah, membantu mendiagnosis penyakit infeksi, serta mengetahui kelainan sistemik pada ginjal dan hati.

Perlakuan pemberian ketiga jenis ransum selama 90 hari tidak berpengaruh nyata $(P>0,05)$ terhadap nilai hemoglobin dan leukosit tikus percobaan (Tabel 6). Hal ini menunjukkan konsumsi tempe dan kedelai rebus memberikan asupan zat besi yang cukup untuk sintesis hemoglobin. Kadar hemoglobin tikus pada ketiga kelompok perlakuan berkisar 13,4-13,8 g/dL. Menurut Arrington (1972), nilai normal hemoglobin pada tikus percobaan adalah 12,0-17,5 $\mathrm{g} / \mathrm{dL}$. Dengan demikian kadar hemoglobin tikus pada ketiga kelompok perlakuan tergolong normal. Nilai leukosit ketiga kelompok tikus berkisar 7,4-8,3 ribu/ $\mathrm{mm}^{3}$, masih masuk dalam kategori normal, yaitu dalam kisaran $5-25 \mathrm{ribu} / \mathrm{mm}^{3}$ (Arrington, 1972). Dengan demikian konsumsi tepung tempe dan tepung kedelai rebus tidak menimbulkan kelainan pada leukosit.

Nilai trombosit tikus kelompok ransum tempe nyata lebih tinggi $(P<0,05)$ dibandingkan tikus pada kelompok ransum kedelai rebus, namun tidak berbeda nyata dengan tikus kelompok ransum kasein. Tingginya nilai trombosit yang diperoleh pada tikus kelompok ransum tempe dapat mendukung penggunaan tempe sebagai pangan alternatif untuk meningkatkan nilai trombosit pada penderita demam berdarah. Nilai eritrosit tikus kelompok ransum tempe tidak berbeda dengan tikus kelompok ransum kasein dan kedelai rebus. Hasil analisis eritrosit ini mendukung penggunaan tempe sebagai bahan alternatif untuk meningkatkan jumlah eritrosit pada penderita anemia. Jumlah eritrosit tikus pada ketiga kelompok perlakuan berada pada kisaran normal, yaitu 7,2-9,6 juta/mm $\mathrm{mm}^{3}$ (Arrington, 1972). Dengan demikian konsumsi tempe dan kedelai rebus dapat mencegah terjadinya anemia akibat menurunnya jumlah eritrosit.

Tabel 6. Nilai hematologi tikus yang diberi pakan kasein, tepung tempe dan tepung kedelai rebus setelah 90 hari percobaan

\begin{tabular}{|c|c|c|c|}
\hline \multirow{2}{*}{ Parameter } & \multicolumn{3}{|c|}{$\begin{array}{l}\text { Kelompok Perlakuan } \\
\text { (Sumber Protein) }\end{array}$} \\
\hline & Kasein & $\begin{array}{l}\text { Tepung } \\
\text { Tempe }\end{array}$ & $\begin{array}{c}\text { Tepung Kedelai } \\
\text { Rebus }\end{array}$ \\
\hline $\begin{array}{l}\text { Hemoglobin } \\
(\mathrm{g} / \mathrm{dL})\end{array}$ & $\begin{array}{c}13,6 \pm \\
0,7^{\mathrm{a}}\end{array}$ & $\begin{array}{c}13,8 \pm \\
0,3^{\mathrm{a}}\end{array}$ & $\begin{array}{c}13,4 \pm \\
0,3^{\mathrm{a}}\end{array}$ \\
\hline $\begin{array}{l}\text { Leukosit } \\
\left(\text { ribu/mm }{ }^{3}\right)\end{array}$ & $\begin{array}{l}7,4 \pm \\
2,8^{\mathrm{a}}\end{array}$ & $\begin{array}{l}7,4 \pm \\
0,5^{\mathrm{a}}\end{array}$ & $\begin{array}{l}8,3 \pm \\
1,8^{a}\end{array}$ \\
\hline $\begin{array}{l}\text { Trombosit } \\
\left(\text { ribu } / \mathrm{mm}^{3}\right)\end{array}$ & $\begin{array}{l}583,2 \pm \\
42,0^{\mathrm{ab}}\end{array}$ & $\begin{array}{c}606,8 \pm \\
22,9^{\mathrm{b}}\end{array}$ & $\begin{array}{c}524,0 \pm \\
63,6^{\mathrm{a}}\end{array}$ \\
\hline $\begin{array}{l}\text { Eritrosit } \\
\left.\text { (juta/mm } \mathrm{mm}^{3}\right)\end{array}$ & $\begin{array}{l}8,1 \pm \\
0,5^{b}\end{array}$ & $\begin{array}{l}8,0 \pm \\
0,2^{a b}\end{array}$ & $\begin{array}{l}7,5 \pm \\
0,4^{a}\end{array}$ \\
\hline
\end{tabular}

Keterangan: Nilai yang diikuti oleh huruf yang berbeda pada baris yang sama menunjukkan berbeda nyata $(P<0,05)$

\section{Kadar malonaldehida hati dan ginjal}

Astuti et al. (2009) menyebutkan malonaldehida (MDA) merupakan hasil proses oksidasi lemak tidak jenuh jamak oleh senyawa radikal bebas di dalam tubuh, sehingga MDA dapat digunakan sebagai indikator keberadaan radikal bebas dan indikator kerusakan oksidatif membran sel di dalam tubuh. Hati merupakan organ yang memiliki fungsi utama dalam menyimpan, melakukan metabolisme dan biosintesis zat gizi. Ginjal merupakan organ yang berfungsi untuk mengeluarkan kotoran dari sistem saluran kemih, menyaring kotoran dari darah, dan menyerap nutrisi penting ke aliran darah (Odden et al., 2014). Kedelai dan tempe merupakan bahan pangan alami yang mengandung antioksidan berupa isoflavon. Isoflavon mampu merangsang ekspresi Cu-Zn SOD yang dapat melindungi sel dari stress oksidatif (Astuti et al., 2009). Pemberian ransum yang berbeda memberikan hasil yang berbeda nyata $(P<0,05)$ pada kadar malonaldehida (MDA) organ hati dan ginjal tikus percobaan (Tabel 7).

Tabel 7. Kadar malonaldehida dan superoksida dismutase pada hati dan ginjal tikus yang diberi pakan kasein, tepung tempe dan tepung kedelai rebus setelah 90 hari percobaan

\begin{tabular}{lccccc}
\hline \multirow{2}{*}{ Kelompok Perakuan } & \multicolumn{2}{c}{ Kadar MDA $(\mu \mathrm{mol} / \mathrm{G})$} & & \multicolumn{2}{c}{ Kadar SOD $(\mu \mathrm{mol} / \mathrm{G})$} \\
\cline { 2 - 3 } \cline { 5 - 6 } & Hati & Ginjal & & Hati & Ginjal \\
\hline Kasein & $19,6 \pm 4,8^{\circ}$ & $13,4 \pm 1,2^{\mathrm{a}}$ & & $344,1 \pm 75,0^{\mathrm{a}}$ & $439,6 \pm 0,7^{\mathrm{a}}$ \\
Tepung tempe & $15,3 \pm 1,4^{\text {ab }}$ & $10,6 \pm 2,1^{\text {ab }}$ & & $367,9 \pm 0,5^{\mathrm{a}}$ & $451,5 \pm 21,2^{\mathrm{a}}$ \\
Tepung kedelai rebus & $9,9 \pm 1,3^{\mathrm{a}}$ & $8,0 \pm 0,7^{\mathrm{a}}$ & & $379,9 \pm 75,0^{\mathrm{a}}$ & $439,6 \pm 0,5^{\mathrm{a}}$ \\
\hline
\end{tabular}

Keterangan: Nilai yang diikuti oleh huruf yang berbeda pada kolom yang sama menunjukkan berbeda nyata $(P<0,05)$ 
Nilai MDA hati dan MDA ginjal tikus kelompok ransum tempe tidak berbeda nyata $(P>0,05)$ dengan tikus kelompok ransum kasein dan kelompok ransum kedelai rebus. Hasil ini sejalan dengan penelitian sebelumnya yang melaporkan bahwa tempe mampu mengurangi atau menghilangkan radikal bebas karena adanya isoflavon yang dapat mencegah terjadinya peroksidasi lipid (Desminarti et al., 2012). Menurut Astawan (2008) kadar isoflavon total yang terdapat pada kedelai mentah sebesar $140 \mathrm{mg} / 100 \mathrm{~g}$ bahan, lebih ting gi dibandingkan yang terdapat pada tempe yaitu sebesar $50 \mathrm{mg} / 100 \mathrm{~g}$ bahan. Namun isoflavon yang terdapat pada tempe sudah dalam bentuk bebas (aglikon) akibat adanya proses fermentasi sehingga lebih mudah diserap oleh tubuh untuk digunakan sebagai antioksidan (Utari et al., 2010; Astuti, 2008). Kandungan isoflavon pada tempe mampu membantu aktivitas antioksidan SOD dalam menghambat terbentuknya radikal bebas (Astuti et al., 2009). Di dalam tubuh, isoflavon dan SOD sama-sama berperan sebagai antioksidan yang dapat menghambat proses oksidasi lemak menjadi MDA. Hal inilah yang menyebabkan kemampuan ransum tempe sama dengan ransum kedelai dalam menekan terbentuknya MDA pada organ hati dan ginjal tikus percobaan.

\section{Kadar superoksida dismutase hati dan ginjal}

Enzim superoksida dimutase (SOD) memiliki peran penting dalam sistem pertahanan tubuh, terutama terhadap aktivitas senyawa oksigen reaktif yang dapat menimbulkan stress oksidatif. SOD dalam tubuh mempunyai aktivitas mengatalisis radikal superoksida $\left(\mathrm{O}_{2}\right)$ menjadi hidrogen peroksida dan oksigen. Konsumsi ransum kasein, tepung tempe, dan tepung kedelai rebus tidak berpengaruh nyata $(P>0,05)$ terhadap kadar enzim SOD organ hati dan ginjal tikus percobaan (Tabel 7). Hal ini kemungkinan disebabkan oleh dua hal, yaitu kadar MDA yang terbentuk pada organ hati dan ginjal tikus belum terlalu banyak sehingga tidak berdampak pada penurunan SOD, atau karena kadar isoflavon pada tempe dan kedelai rebus mampu mengatasi serangan radikal bebas pada kedua organ tersebut.

\section{KESIMPULAN}

Food convertion efficiency tikus kelompok tempe nyata lebih tinggi $(P<0,05)$ dibandingkan tikus kelompok kasein dan kelompok kedelai rebus. Hal ini menunjukkan kualitas protein tempe dari kedelai lokal Grobogan lebih baik dibandingkan kasein. Konsumsi tempe kedelai Grobogan dalam jangka panjang tidak berpengaruh terhadap organ tubuh, terutama pada hati, ginjal dan testis tikus percobaan. Konsumsi tempe dari kedelai Grobogan dalam jangka panjang juga tidak menimbulkan kelainan pada biokimia serum dan hematologi tikus percobaan. Dibandingkan dengan tikus kelompok kedelai rebus dan kasein, maka tikus kelompok tempe memiliki kolesterol HDL yang lebih tinggi, tetapi tidak berbeda nyata pada parameter hematologi, MDA dan SOD hati dan ginjal tikus percobaan. Hal ini menunjukkan konsumsi tempe dari kedelai Grobogan dalam jangka panjang tidak berdampak negatif terhadap kesehatan.

\section{UCAPAN TERIMAKASIH}

Peneliti mengucapkan terima kasih kepada pemberi dana penelitian, yaitu Direktorat Penelitian dan Pengabdian kepada Masyarakat, Direktorat Jenderal Pendidikan Tinggi, Kementerian Ristek Dikti, melalui skema "Hibah Kompetensi 2015" atas nama Made Astawan.

\section{DAFTAR PUSTAKA}

Aboderin FI, Oyetayo VO. 2006. Haematological studies of rats fed different doses of probiotic, Lactobacillus plantarum, isolated from fermenting corn slurry. Pak J Nutr 5: 102-105. DOI: 10.3923/pjn.2006.102.105.

Anderson JW, Bush HM. 2011. Soy protein effects on serum lipoproteins: a quality assessment and meta-analysis of randomized controlled studies. J Am Coll Nutr 30: 79-91.

[AOAC] Association of Official Analytical Chemist. 2005. Official Method of Analysis of The Association of Official Analysis Chemist. Washington DC (USA): AOAC Inc.

Appenzeller LM, Munley SM, Hoban D, Skyes GP, Malley LA, Delaney B. 2008. Subchronic feeding study of herbicide-tolerant soybean DP 356 $643-5$ in sparague-dawley rats. Food Chem Toxicol 46: 2201-2213. DOI: 10.1016/j.fct. 2008.02.017.

Arrington LR. 1972. Introductory Laboratory Animal Science. 8-9. The Interstate Printers \& Publishers, Inc., Danville, Illinois.

Astawan M, Wresdiyati T, Hartanta AB. 2005. Pemanfaatan rumput laut sebagai sumber serat pangan untuk menurunkan kolesterol darah tikus. J Hayati 12: 23-27.

Astawan M. 2008. Sehat dengan Tempe, Panduan Lengkap Menjaga Kesehatan dengan Tempe. Jakarta (ID): Dian Rakyat.

Astawan M. 2009. Panduan Karbohidrat Terlengkap. 25-34. Dian Rakyat, Jakarta.

Astawan M. 2013. Soy story. Food Review VIII: 4651 
Astawan M, Adiningsih NR, Palupi NS. 2014. Evaluasi kualitas nuget tempe dari berbagai varietas kedelai. Pangan: Med Kom Informasi 23: 244-255.

Astawan M, Wresdiyati T, Saragih AM. 2015. Evaluasi mutu protein tepung tempe dan tepung kedelai rebus pada tikus percobaan. $J$ Mutu Pangan 2: 11-17.

Astawan M. 2015. Rumah Tempe Indonesia: a Center of Excellence for Tempe Industry. Conference Handbook: International Conference on Tempe. Yogyakarta, February $15-17^{\text {th }}$ 2015.

Astuti S. 2008. Isoflavon kedelai dan potensinya sebagai penangkap radikal bebas. J Teknol Industri Hasil Pert 13: 126-136.

Astuti S, Muchtadi D, Astawan A, Purwantara B, Wresdiyati T. 2009. Pengaruh pemberian tepung kedelai kaya isoflavon terhadap kadar malonaldehida, aktivitas superoksida dismutase testis dan profil $\mathrm{Cu}, \mathrm{Zn}-\mathrm{SOD}$ tubuli seminiferi testis tikus jantan. $J$ Teknol Industri Pangan 20: 129-134.

Babu PD, Bhakyaraj R, Vidhyalakshmi R. 2009. A low cost nutritious food "Tempeh"-a review. World J Dairy Food Sci 4: 22-27.

Daleprane JB, Feijo TS, Boaventura GT. 2009. Organic and genetically modified soybean diets: consequences in growth and hematological indicators of aged rats. Plant Food Hum Nutr 64: 1-5. DOI: 10.1007/s11 130-008-0101-0.

Desminarti S, Rimbawan, Anwar F, Winarto A. 2012. Efek bubuk tempe instan terhadap kadar malonadehid (MDA) serum tikus hiperglikemik. J Kedokteran Hewan 6: 197-205.

Maskar DH, Hardinsyah, Damayanthi E, Astawan M, Wresdiyati T. 2015. Effects of genetically modified (GM) soybean and tempe consumption on blood profile, malondialdehyde (MDA) level and superoxide dismutase (SOD) activity of Sprague-Dawley rats. Int J Sci Basic Appl Res 23: $271-285$

Messina M, Messina VL, Chan P. 2011. Soy foods, hyperuricemia and gout: a review of the epidemiologic and clinical data. Asia Pac J Clin Nutr 20: 347-358

Misra HP, Fridovich I. 1972. The role of superoxide anion in the autoxidation of epinephrine and a simple assay for superoxide dismutase. J Biol Chem 247: 3170-3175.
Muchtadi M, Palupi NS, Astawan M. 1992. Metode Kimia Biokimia dan Biologi dalam Evaluasi Nilai Gizi Pangan Olahan. 67-74 Pusat Antar Universitas Pangan dan Gizi, Institut Pertanian Bogor, Bogor.

Mursyid, Astawan M, Muchtadi D, Wresdiyati T, Widowati S, Bintari SH, Suwarno M. 2014. Evaluasi nilai gizi protein tepung tempe yang terbuat dari varietas kedelai impor dan lokal. J Pangan 23: 33-41.

Nout MJR, Kiers JL. 2005. Tempe fermentation, innovation and functionality: update into the third millenium. J Appl Microbiol 98: 789-805. DOI: 10.1111/j.1365-2672.2004.02471.x.

Odden MC, Amadu AR, Smit E, Lo L, Peralta CA. 2014. Uric acid levels, kidney function, and cardiovascular mortality in US adults: national health and nutrition examination survey (NHANES) 1988-1994 and 1999-2002. Am J Kidney Dis 64: 550-557. DOI: 10.1053/j.ajkd. 2014.04.024.

Qi X, He X, Luo Y, Li S, Zou S, Cao S, Tang M, Delaney B, Xu W, Huang K. 2012. Subchronic feeding study of stacked trait geneticallymodified soybean (3Ø5423 $\times$ 40-3-2) in sparague-dawley rats. Food Chem Toxicol 50: 3256-3263. DOI: 10.1016/j.fct.2012.06. 052.

Suwarno M, Astawan M, Wresdiyati T, Widowati S, Bintari SH, Mursyid. 2013. Evaluasi keamanan tempe dari kedelai transgenik melalui uji subkronis pada tikus. J Veteriner 15: 353-362.

Turner AH, Pike MJ, Francis MA. 2008. Haematology what does your blood test mean ?. http:// mams.rmit.edu.au/hgfc58lk9pwc1.pdf [19 Mei 2015].

Utari DM, Rimbawan, Riyadi H, Muhilal, Purwantyastuti. 2010. Pengaruh pengolahan kedelai menjadi tempe dan pemasakan tempe terhadap kadar isoflavon. J Penel Gizi Makanan 33: 148153.

Villegas R, Gao YT, Yang G, Li HL, Elasy TA, Zheng W, Shu XO. 2008. Legume and soy food intake and the incidence of type 2 diabetes in the Shanghai women's health study. Am J Clin Nutr 87: 162-167.

Watanabe N, Fujimoto K, Aoki H. 2007. Antioxidant activities of the water soluble fraction in tempeh like fermented soybean (GABA-tempeh). Int $\mathrm{J}$ Food Sci Nutr 58: 577-587. DOI: 10.1080/09 637480701343846. 